PRICE THEORY 

Nobel Laureate in Economics

\section{MILTON FRIEDMAN}

$\stackrel{W}{D E}^{W}$

Walter de Gruyter

Berlin • New York 


\section{About the Author}

Milton Friedman is a Senior Research Fellow at the Hoover Institution (Stanford University) and is Paul Snowden Russell Distinguished Service Professor of Economics, University of Chicago; a member of the research staff, National Bureau of Economics Research; a past President of the American Economic Association; and a fellow of the Econometric Society, the American Statistical Association, and the Institute of Mathematical Statistics. The recipient of the Nobel Prize for economics in 1976, he is the author of many journal articles and books. Among his best known works are Essays in Positive Economics, Studies in the Quantity Theory of Money, A Theory of the Consumption Function, A Program for Monetary Stability, Capitalism and Freedom, Dollars and Deficits: Inflation, Monetary Policy and the Balance of Payments. The Optimum Quantity of Money and Other Essays, A Monetary History of the United States (with Anna J. Schwartz), Monetary Statistics of the United States (with Anna J. Schwartz), Money and Economic Development, There's No Such Thing as a Free Lunch, Free to Choose (with Rose Friedman), and Monetury Trends in the United States and the United Kingdom (with Anna J. Schwartz).

Copyright (c) 1962, 1976 by Aldine Publishing Company, New York

All rights reserved. No part of this publication may be reproduced or transmitted in any form or by any means, electronic or mechanical, including photocopy, recording, or any information storage and retrieval system, without permission in writing from the publisher.

ISBN 3-1 1-010987-5

Library of Congress Catalog Card Number 76-1397

Printed in the United States of America

Fourth printing, 1986 